\title{
STRATEGI KOMUNIKASI DALAM MENGIMPLEMENTASIKAN KEGIATAN SIMPAN PINJAM PEREMPUAN PADA PNPM MANDIRI PERDESAAN
}

\author{
Israyanti $^{1)}$, Jeanny Maria Fatimah ${ }^{2)}$, Rahman Saeni $^{3)}$ \\ ${ }^{1}$ Fakultas Ilmu Sosial Dan Ilmu Politik, Universitas Hasanuddin \\ Email: Izrayanti@gmail.com \\ ${ }^{2}$ Fakultas Ilmu Sosial Dan Ilmu Politik, Universitas Hasanuddin \\ Email: jenny.palinggi@yahoo.com \\ ${ }^{3}$ Fakultas Ilmu Sosial Dan Ilmu Politik, Universitas Hasanuddin
}

\begin{abstract}
The purpose of this research was to determine how the communication strategy to implement the activity of Women Finance at the National Program of Rural Community Self-Empowerment and to disclose the supporting and inhibiting factors in implementing the Woman Finance activity at the National Program of Rural Community SelfEmpowerment. This type of research is descriptive with used qualitative method. The research informants were determined by using purposive sampling based on certain criteria. The result of the research shows the communication strategy applied by the managers in implementing the Activity of Women Finance related to the identifying the audience, arranging the message, establishing the method, choosing the use of media and the role of communicator. The study also found that there are several supporting during the process implementation of Women Finance activity such as support from the government at the district, sub-district, and village levels, financial support and that is not less important, enthusiasm and support from the community. While the inhibiting factors are the delay in making reports and the inactivity of the people involved in the Women Finance program as well as the difficulty of scheduling activities for the community.
\end{abstract}

Keyword: Communication Strategy, Activity of Women Finance

\begin{abstract}
ABSTRAK
Tujuan penelitian ini adalah untuk mengetahui strategi komunikasi dalam mengimplementasikan kegiatan SPP pada PNPM mandiri perdesaan dan untuk mengetahui faktor pendukung dan penghambat dalam mengimplementasikan kegiatan SPP pada PNPM mandiri perdesaan. Tipe penelitian bersifat deskriptif dengan menggunakan metode kualitatif. Teknik penentuan informan dalam penelitian ini menggunakan teknik purposive sampling berdasarkan kriteria-kriteria tertentu. Hasil penelitian menunjukkan strategi komunikasi yang diterapkan pihak pengelola dalam mengimplementasikan kegiatan simpan pinjam perempuan (SPP) berkaitan dengan persoalan pengenalan khalayak; penyusunan pesan; penetapan metode penyampaian pesan; pemilihan media; dan peranan komunikator. Penelitian ini juga menemukan bahwa ada beberapa faktor pendukung selama proses pengimplemetasian kegiatan SPP diantaranya adanya dukungan dari pemerintah baik itu ditingkat kabupaten, kecamatan, maupun desa, dukugan finansial dan yang tak kalah penting dukungan, antusiasme dan patisipasi dari masyarakat. Sementara untuk faktor penghambatnya yaitu keterlambatan pencairan dana dan pembuatan laporan, ketidakaktifan dari pelaku-pelaku yang terkait dalam kegiatan SPP, serta susahnya penjadwalan kegiatan untuk masyarakat.
\end{abstract}

Kata kunci: Strategi Komunikasi, Kegiatan Simpan Pinjam Perempuan 


\section{PENDAHULUAN}

Salah satu permasalahan yang tak kunjung tuntas dihadapi Indonesia sampai saat ini ialah masalah kemiskinan. Berbagai upaya yang dilakukan pemerintah dalam penanggulangan kemiskinan ini. Salah satunya dengan dihadirkannya program nasional pemberdayaan masyarakat (PNPM) Mandiri Perdesaan. PNPM Mandiri Perdesaan telah dilaksanakan sejak tahun 2007 pada masa pemerintaan Susilo Bambang Yudiono. PNPM Mandiri Perdesaan dimaksudkan untuk menjadi payung program penanggulangan kemiskinan dengan menggunakan pendekatan pembangunan berbasis masyarakat (PNPM, 2012-2013).

Secara umum ada 3 ruang lingkup utama dari PNPM Mandiri Perdesaan yaitu perbaikan dan penyediaan sarana dan prasarana (pembangunan infrastruktur), peningkatan kualitas sumber daya manusia, dan penyediaan sumber keuangan melalui dana bergulir yang didalamnya terdiri dari 2 kegiatan yaitu usaha ekonomi produktif (UEP) dan simpan pinjam perempuan (SPP). Kegiatan SPP inilah yang menjadi fokus pada penelitian ini. Kegiatan SPP sendiri diperuntukkan sebagai bantuan modal kerja terhadap usaha agar masyarakat dapat meningkatkan produktivitas perekonomiannya. Selain itu, alokasi pinjaman atau bantuan modal kerja diprioritaskan bagi masyarakat miskin yang memiliki usaha produktif (Nihayah, 2015:4).

Secara umum, kegiatan SPP dapat berjalan dengan baik apabila seluruh unsurunsur yang terlibat dapat bekerja secara efektif. Namun pada kenyataannya, ditinjau dari aspek pengelolaaan kegiatan kelompok tidak semua simpan pinjam khusus perempuan tersebut dapat mengelolah kegiatan mereka masingmasing sehingga tujuan yang ingin dicapai tidak sesuai dengan hasil yang diperoleh dari usaha yang dijalankan. Permasalahan seperti ini pula yang terjadi di Kecamatan Tomoni khususnya di Kelurahan Tomoni. Dari 12 desa dan 1 kelurahan yang ada, wilayah yang paling sering bermasalah pada kegiatan simpan pinjam perempuannya (SPP) ialah di Kelurahan Tomoni. Berdasarkan data yang diperoleh penulis menunjukkan bahwa pada awal pelaksanaan kegiatan, Kelurahan Tomoni memiliki 22 kelompok SPP namun saat ini yang masih bertahan hanya 4 kelompok saja. Selain itu, data tersebut diperkuat pula dengan hasil wawancara yang dilakukan kepada ketua unit pengelola kegiatan (UPK) Kecamatan Tomoni yang mengatakan bahwa hal tersebut terjadi karena penduduk yang meminjam bantuan dana melalui kegiatan SPP banyak yang melakukan penunggakan dan akhirnya memutuskan untuk lari atau pergi dari daerah tersebut tanpa mengembalikan pinjaman dan kebanyakan penduduk yang melakukan hal ini ialah penduduk pendatang yang berdomisili atau menetap untuk tinggal di daerah tersebut. Padahal rata-rata pekerjaan penduduk yang ada di Kelurahan Tomoni ialah pedagang atau wiraswasta, sehingga untuk implementasi kegiatan SPP ini akan sangat berguna/cocok sebagai bantuan modal untuk masyarakat yang mempunyai usaha produktif.

Masih terdapatnya permasalahan yang terserap dalam pelaksanaan kegiatan SPP di Kelurahan Tomoni Kecamatan Tomoni Kabupaten Luwu Timur, menjadi suatu ketertarikan peneliti untuk mengetahui bagaimana strategi komunikasi yang digunakan dalam mengimplementasikan kegiatan SPP pada PNPM mandiri perdesaan dan apa saja faktor pendukung dan penghambat dalam mengimplementasikan kegiatan SPP pada PNPM mandiri perdesaan.

\section{KAJIAN LITERATUR}

Dalam sebuah komunikasi, strategi merupakan suatu hal yang penting terlebih apabila komunikasi itu adalah komunikasi yang dilancarkan oleh sebuah organisasi misalnya komunikasi politik dan komunikasi bisnis. Komunikasi merupakan proses yang rumit. Dalam rangka menyusun strategi komunikasi diperlukan suatu pemikiran dengan memperhitungkan faktor pendukung dan faktor penghambatnya.

Mengimplementasikan kegiatan simpan pinjam perempuan (SPP) diperlukan strategi, seperti yang diungkapakan oleh Onong Uchjana (2003:299) bahwa berhasil atau tidaknya sebuah kegiatan komunikasi secara efektif banyak ditentukan oleh strategi komunikasi. Strategi komunikasi erat hubungannya antara tujuan yang hendak dicapai dengan konsekuensi-konsekunsi (masalah) yang harus diperhatikan, kemudian merencanakan bagaimana konsekuensikonsekuensi ini sesuai dengan hasil yang diharapkan atau tujuan yang akan dicapai. Strategi komunikasi dapat pula diartikan sebagai suatu cara atau taktik rencana dasar yang menyeluruh dari rangkaian tindakan yang 
akan dilaksanakan oleh sebuah organisasi untuk mencapai suatu tujuan atau beberapa sasaran dengan memiliki sebuah panduan perencanaan komunikasi (communication planning) dengan manajemen komunikasi (management communication) untuk mencapai tujuan yang diterapkan.

Sebelum menerapkan sebuah strategi komunikasi tentu saja perlu diketahui tujuan sentral dari strategi komunikasi itu sendiri. Seperti yang dikemukakan oleh R.Wayne Pace, Brent D. Petersondan, dan M.Dallas Burnet dalam bukunya Technique for Effective Communication bahwa tujuan sentral strategi komunikasi terdiri atas empat tujuan utama, yaitu :

1. To secure understanding (untuk memastikan bahwa terjadi suatu pengertian dalam berkomunikasi)

2. To establish acceptance (bagaimana cara penerimaan itu terus dibina dengan baik)

3. To motivate action (penggiatan untuk memotivasinya)

4. The goals which the communicator sought to achieve (bagaimana mencapai tujuan yang hendak dicapai oleh pihak komunikator dari proses komunikasi tersebut).

Selain itu, Arifin juga menyebutkan bahwa dalam merumuskan strategi komunikasi terdapat 5 (lima) faktor yang harus diperhatikan, yakini;

\section{Mengenal Khalayak}

Jadi dalam merumuskan strategi komunikasi kita harus memperhitungkan suatu kondisi dan situasi khalayak. Itulah sebabnya maka langkah pertama yang harus dilakukan adalah mengenal khalayak. Kenallah khalayakmu adalah pinsip dasar dalam berkomunikasi. Karena mengetahui dan memahami karakteristik khalayak, berarti suatu peluang untuk mencapai keberhasilan komunikasi. (Cangara, 2010)

Menyusun Pesan

Setelah khalayak dan situasi diketahui dengan jelas, selanjutnya langkah perumusan strategi komunikasi ialah menyusun pesan, yaitu menentukan tema dan materi dengan orientasi agar mampu membangkitkan perhatian. Pesan mempunyai kedudukan sentral yang tidak boleh terabaikan dalam mencapai efektivitas komunikasi. Pesan akan sangat bergantung dengan program yang akan disampaikan.

\section{Menetapkan Metode}

Pemilihan metode harus disesuaikan dengan bentuk pesan, keadaan khalayak, fasilitas dan biaya. Terkait dengan metode penyampaian pesan, Arifin (1984:72-78) membedakan berdasarkan dua aspek: menurut cara pelaksanaannya dan bentuk isinya. Menurut cara pelaksanaannya meliputi redundancy (repetition) dan canalizing. Sedangkan menurut bentuk isinya meliputi informative, persuasive, educative dan cursive.

\section{Pemilihan penggunaan media}

Pemilihan media dalam strategi komunikasi merupakan pilihan yang ditentukan oleh komunikator terhadap media apa yang dianggap paling cocok dimanfaatkan dalam menyampaikan pesannya.

\section{Peranan Komunikator}

Dalam proses komunikasi, komunikator memegang peran penting terhadap keberhasilan komunikasi. Para ahli komunikasi cenderung sependapat bahwa dalam melancarkan komunikasi lebih baik menggunakan teori atau pendekatan AIDDA yang terdiri dari A: Attention (perhatian), I: Interest (minat), D: Desire (hasrat), D: Decision (keputusan), A: Action (kegiatan). Proses pentahapan komunikasi ini mengandung maksud bahwa komunikasi sehendaknya dimulai dengan membangkitkan perhatian (attention) sebagai awal suksesnya komunikasi. Kemudian dilanjutkan dengan menumbuhkan minat, hasrat dan keputusan yang diakhiri dengan datangnya sebuah tindakan. Dalam penelitian ini, teori AIDDA digunakan untuk melihat peran komunikator sebagai penyampai pesan yang berperan penting. Strategi komunikasi yang dilakukan harus luwes sehingga komunikator sebagai pelaksana dapat segera mengadakan perubahan apabila ada suatu faktor yang mempengaruhi. Untuk menjalankan semua proses tersebut tentunya ada fakor penting pada diri komunikator yang harus dimiliki bila ingin melancarkan komunikasinya, yaitu daya tarik (source attractiveness) dan kreadibilitas sumber (source credibility). 


\section{METODE PENELITIAN}

Penelitian ini dilakukan selama 3 bulan yaitu mulai bulan Januari sampai dengan bulan April 2017 dengan tempat penelitian di Kelurahan Tomoni Kecamatan Tomoni Kabupaten Luwu Timur. Tipe penelitian ini bersifat deskriptif dengan menggunakan metode kualitatif. Kemudian pendekatan yang digunakan adalah studi kasus. Pendekatan tersebut dilakukan kepada orang-orang yang terkait dengan kegiatan simpan pinjam perempuan (SPP) di Kelurahan Tomoni yang sesuai dengan kriteria penelitian.

Teknik yang digunakan untuk pengumpulan data dalam penelitian ini meliputi: (a) Data primer, terdiri dari observasi (non-partisipant) dan wawancara. (b) Data sekunder yang diperoleh melalui studi kepustakaan seperti bahan bacaan buku, jurnal, artikel, penelitian sebelumnya dan bahan kuliah yang berhubungan dengan masalah yang dalam penelitian ini.

Teknik penentuan informan yang digunakan dalam penelitian ini adalah teknik purposive sampling dengan mengambil 4 informan dari pelaku (komunikator) yang terlibat dalam pengimplementasian kegiatan SPP dalam hal ini pihak pengelola kegiatan SPP dan 4 informan dari penerima manfaat dalam hal ini masyarakat yang mengikuti kegiatan SPP.

Data penelitian ini dianalisis berdasarkan model dari Miles dan Huberman (Usman \& Akbar, 2009:85) yakni dimulai dengan pengumpulan data melalui wawancara dengan informan maupun observasi terhadap kegiatan SPP, kemudian dilanjutkan dengan reduksi data yakni merangkum dan memilah serta memfokuskan hal-hal yang pokok dan penting. Selanjutnya data disajikan dalam bentuk teks yang bersifat deskriptif dan diakhiri dengan penarikan kesimpulan dan verifikasi.

\section{HASIL DAN PEMBAHASAN}

\section{HASIL PENELITIAN}

\section{Identitas Diri Informan}

Teknik penentuan informan dalam penelitian ini adalah purposive sampling dengan kriteria informan adalah orang-orang yang benar-benar mengetahui dan terlibat langsung pada perumusan dan pelaksanaan strategi komunikasi kegiatan SPP di Kelurahan Tomoni Kecamatan Tomoni Kabupaten Luwu Timur, sehingga penulis dapat merangkum informasi yang tepat dan dapat dipercaya. Informan tersebut berjumlah 8 (delapan) orang, seperti terlihat pada Tabel 1.

\section{Strategi Komunikasi Dalam \\ Mengimplementasikan Kegiatan Simpan \\ Pinjam Perempuan (SPP) Pada PNPM \\ Mandiri Perdesaan}

Strategi komunikasi pada dasarnya bisa diaplikasikan untuk banyak hal, bukan hanya untuk komunikasi itu sendiri, tapi juga bisa digunakan oleh lembaga-lembaga yang berusaha mendapatkan dukungan dari masyarakat seperti halnya pada program nasional pemberdayaan masyarakat (PNPM).

Keberhasilan kegiatan komunikasi secara efektif banyak ditentukan oleh penentuan strategi komunikasi. Di lain pihak jika tidak ada strategi komunikasi yang baik efek dari proses komunikasi bukan tidak mungkin akan menimbulkan pengaruh negatif. Sedangkan untuk menilai proses komunikasi dapat ditelaah dengan menggunakan elemenelemen komunikasi yang terdiri dari komunikator, pesan, saluran, komunikan, dan efek.

Berdasarkan penelitian yang dilakukan selama kurang lebih tiga bulan, penulis berhasil mengumpulkan data melalui observasi dan wawancara mengenai strategi komunikasi dalam mengimplementasikan kegiatan simpan SPP pada PNPM mandiri perdesaan di Kel. Tomoni, Kec. Tomoni, Kab. Luwu Timur. Dari data tersebut, ditemukan bahwa strategi komunikasi yang digunakan pihak pengelola kegiatan SPP terdiri dari:

\section{Mengenal Khalayak}

Berdasarkan hasil penelitian, Dalam perumusan strategi komunikasi unit pengelola kegiatan dan pihak-pihak yang terkait terhadap 
implementasi kegiatan SPP di Kecamatan Tomoni, yang menjadi khalayaknya adalah semua masyarakat yang masuk dalam kategori kelas menengah ke bawah. Khalayak tersebut adalah masyarakat miskin yang membutuhkan bantuan modal dan ingin berusaha untuk mengembangkan usahanya.

Selain itu, pihak pengelola kegiatan SPP di kecamatan Tomoni dalam mengenal khalayak sebelumnya juga melakukan observasi di lapangan terhadap kelompok masyarakat yang mengajukan pinjaman, apakah layak untuk di berikan atau tidak berdasarkan hasil penilaian yang dilakukan.

\section{Menyusun Pesan}

Setelah mengenal khalayak dan situasinya, maka langkah selanjutnya dalam perumusan strategi komunikasi ialah menyusun pesan, yaitu menentukan tema dan materi. Berdasarkan hasil penelitian, ada dua jenis penyusunan pesan yang dilakukan pihak pengelola kegiatan SPP di Kelurahan Tomoni Kecamatan Tomoni yakni pesan verbal dan non verbal. Pesan verbal disampaikan melalui lisan dan tulisan. Sementara pesan non verbal adalah pesan yang disampaikan melalui mimik, gesture, gambar, intonasi suara. Pesan verbal dan non verbal ini dapat dilihat dari aktivitas sosialisasi yang dilakukan oleh pihak pengelola kegiatan sebagai penyebaran informasi ke masyarakat.

Sementara untuk penyusunan materi pesan yang disajikan oleh pihak pengelola kegiatan SPP di Kelurahan Tomoni Kecamatan Tomoni disusun berdasarkan pada petunjuk teknis operasional (PTO) PNPM mandiri perdesaan yang sudah ada. Mulai dari landasan hukum, kebijakan, konsep, prosedur, tahap pelaksanaan, syarat-syarat mendaftar, pembentukan kelompok, iuran, dan lain sebagainya.

\section{Menetapkan Metode}

Metode penyampaian pesan menjadi aspek yang tak kalah pentingnya dalam strategi komunikasi. Bagaimanapun menariknya materi sebuah pesan namun jika metode penyampaian pesannya tidak tepat maka pesan tersebut tidak akan sampai pada khalayak sesuai dengan tujuan dilaksanakannya aktivitas komunikasi. Berdasarkan hasil penelitian, unit pengelola kegiatan berserta pihak-pihak yang terkait dalam implementasi kegiatan SPP di Kelurahan
Tomoni Kecamatan Tomoni menggunakan metode penyampaian pesan secara informatif, edukatif, dan persuasif.

\section{Pemilihan Penggunaan Media}

Dari beberapa jenis media yang ada, pihak pengelola kegiatan dalam mengimplementasiakan kegiatan SPP di Kelurahan Tomoni Kecamatan Tomoni menggunakan media komunikasi langsung (misalnya dalam sosialisasi atau pertemuan, simulasi permainan), media tayang (seperti video dan bahan bacaan yang ditampilkan melalui slide power point), dan media lini bawah (seperti booklet, brosour, selebaran dan papan informasi).

\section{Peranan Komunikator}

Ada fakor penting pada diri komunikator bila ia ingin melancarkan komunikasi, yaitu daya tarik (source attractiveness) dan kreadibilitas sumber (source credibility) yang tentunya diiringi dengan rasa empati ke khalayak sasaran.

Berdasarkan hasil penelitian, terkait dengan daya tarik dan kreadibilitas pada diri komunikator, pihak pengelola kegiatan SPP di Kelurahan Tomoni Kecamatan Tomoni sebelum mengimplementasikan program ini ke masyarakat, terlebih dahulu mendapatkan pelatihan (training) terkait penyebaran informasi, prosedur atau tahap pelaksanaan kegiatan yang nantinya akan diberikan ke masyarakat.

Kemudian terkait peranan komunikator dalam implementasi kegiatan SPP yang ada di Kelurahan Tomoni Kecamatan Tomoni sudah dilakukan dengan baik dan sesuai dengan aturan. Hal ini didukung dengan adanya pemberian pemahaman dan motivasi mengenai program PNPM-MPd khususnya kegiatan SPP ke masyarakat penerima manfaat.

\section{Faktor Pendukung dan Penghambat Dalam Mengimplementasikan Kegiatan Simpan Pinjam Perempuan (SPP) PNPM Mandiri Perdesaan}

a. Faktor Pendukung

Kegiatan Simpan Pinjam Perempuan (SPP) merupakan salah satu program penanggulangan kemiskinan berbasis pemberdayaan yang bertujuan untuk meningkatkan kesejahteraan masyarakat dalam 
hal peningkatan kualitas kehidupan. Kesuksesan dalam pelaksanaan program ini tidak akan diraih tanpa adanya dukungandukungan dari berbagai pihak

Dari hasil penelitian, faktor yang sangat mendukung selama pelaksanaan kegiatan SPP ini di Kelurahan Tomoni Kecamatan Tomoni adalah adanya dukungan dari semua kalangan baik itu dari pemerintah, dukungan finansial dan terutama dukungan dari masyarakat.

\section{b. Faktor Penghambat}

Berdasarkan hasil penelitian, faktor penghambat dalam pengimplementasian kegiatan SPP ini tidak lepas dari pelaku-pelaku yang terlibat dalam kegiatan baik itu dari pemerintah setempat maupun dari masyarakatnya itu sendiri.

\section{PEMBAHASAN}

\section{STRATEGI KOMUNIKASI DALAM MENGIMPLEMENTASIKAN KEGIATAN SIMPAN PINJAM PEREMPUAN (SPP) PADA PNPM MANDIRI PERDESAAN}

Untuk membahas bagaimana strategi komunikasi pihak pengelola kegiatan SPP pada PNPM Mandiri Perdesaan di Kelurahan Tomoni Kecamatan Tomoni Kabupaten Luwu Timur maka penulis menggunakan teori atau pendekatan AIDDA yang terdiri dari A: Attention (perhatian), I: Interest (minat), D: Desire (hasrat), D: Decision (keputusan), A: Action (kegiatan). Proses pentahapan komunikasi ini mengandung maksud bahwa komunikasi sehendaknya dimulai dengan membangkitkan perhatian (attention) sebagai awal suksesnya komunikasi. Kemudian dilanjutkan dengan menumbuhkan minat, hasrat dan keputusan yang diakhiri dengan datangnya sebuah tindakan. Dalam penelitian ini, teori AIDDA digunakan untuk melihat peran komunikator sebagai penyampai pesan yang berperan penting. Strategi komunikasi yang dilakukan harus luwes sehingga komunikator sebagai pelaksana dapat segera mengadakan perubahan apabila ada suatu faktor yang mempengaruhi.

Penulis menggunakan teori AIDDA ini untuk memahami situasi dan kondisi dalam penelitian. Kemudian penulis menghubungkan dengan menggunakan konsep atau perumusan strategi komunikasi yang terdiri dari pengenalan khalayak, penyusunan pesan, penetapan metode, pemilihan penggunaan media dan peranan komunikator. Dengan demikian, untuk membangkitkan perhatian khalayak atau masyarakat sampai dengan tahap melakukan action dalam hal ini ikut berpartisipasi dalam kegiatan maka dibutuhkan suatu strategi komunikasi. Strategi komunikasi yang dilakukan pengelola kegiatan dalam mengimplementasikan kegiatan SPP di Kelurahan Tomoni Kecamatan Tomoni Kabupaten Luwu Timur, dilaksanakan dengan cara:

\section{Mengenal Khalayak}

Ditahap pengenalan khalayak ini, pihak pengelola kegiatan SPP di Kelurahan Tomoni Kecamatan Tomoni Kabupaten Luwu Timur berusaha mengenal khalayak baik itu dari calon penerima manfaat ataupun penerima manfaat dengan melihat dari segi latar belakang budaya, pendidikan, kondisi ekonomi, dan kondisi sosial budaya masyarakat setempat.

Pada dasarnya pelaksanaan yang dilakukan oleh pengelola kegitan terkait dengan kegiatan SPP di Kelurahan Tomoni Kecamatan Tomoni dalam mengenal khalayak atau masyarakat yang dituju dalam program ini sudah dapat dikatakan tepat sasaran, karena dalam mengimplementasikannya sudah mengikuti tata cara atau prosedur yang ada dalam petunjuk teknis operasional PNPM mandiri perdesaan, dimana sasaran yang ditujukan pada program ini adalah masyarakat miskin dan sebelum masyarakat menerima bantuan dana terlebih dahulu harus dilakukan verifikasi untuk kelayakan kelompok dan anggota kelompok. Namun, untuk lebih melancarkan jalanya proses pengimplementasian kegiatan SPP ini maka untuk pihak pengelola kegiatan agar lebih meningkatkan lagi ketegasannya dalam memilih khalayak dengan tidak melibatkan unsur-unsur tertentu. Selain itu pengawasan, pemantauan, dan pengontrolan yang lebih juga perlu ditingkatkan kepada masyarakat yang sudah menerima pinjaman dana melalui kegiatan SPP agar ke depannya tidak lagi terjadi penyelewengan.

\section{Menyusun Pesan}

Suatu pesan dapat menarik perhatian jika pesan yang disampaikan itu menyangkut 
kebutuhan dan kepentingan serta memberikan manfaat bagi khalayak yang mendengarnya. Pada dasarnya penyusunan pesan yang dilakukan pihak pengelola kegiatan SPP di Kelurahan Tomoni Kecamatan Tomoni sudah dikatakan tepat karena sekali lagi sudah mengikuti prosedur atau tata cara pelaksanaan serta aturan-aturan dari PTO PNPM mandiri perdesaan.

Hanya saja dibutuhkan penyajian isi pesan yang bersifat Both side issue (kedua belah pihak). Artinya pesan yang disajikan tidak hanya positif saja namun negatifnya juga. Misalnya pihak pengelola kegiatan SPP baik itu ditingkat Kecamatan maupun ditingkat Kelurahan Tomoni tidak hanya memberitahukan aturan-aturan atau tata cara pelaksanaan kegiatan SPP saja tapi perlu juga memberitahukan dan menerapkan sanksi-sanki yang diterima masyarakat penerima manfaat jika tidak mengadakan pertemuan kelompok atau tidak mengikuti setiap sosialisai yang diadakan oleh pihak pengelola kegiatan. Dengan begitu, masyarakat tentunya bisa ikut lebih berpartisipasi dalam pelaksnaan kegiatan SPP ini.

\section{Menetapkan Metode}

Dari hasil penelitian, pihak pengelola kegiatan SPP di Kel.Tomoni, Kec.Tomoni menggunakan metode penyampaian pesan secara informatif, edukatif, dan persuasi. Metode informatif dilakukan sebagai penyebaran atau penyampaian informasi kepada seluruh khalayak sasaran melalui forum sosialisasi dan beberapa saluran komunikasi dengan tujuan untuk membangun pemahaman kepada khalayak sasaran. Sementara untuk metode edukatif dilakukan sebagai proses pembelajaran dalam pelaksanaan program dengan tujuan untuk membangun rasa percaya diri (self confident), rasa mampu diri (self efficacy), dan kesadaran kerjasama. Sedangkan untuk metode persuasif dilakukan untuk membangun keberpihakan, dukungan dan ketertarikan khalayak sasaran terhadap kegiatan SPP ini.

Secara umum, dengan menggunakan metode penyampaian pesan informatif, edukatif, dan persuasif tentu saja sudah dapat melancarkan proses pengimplementasian dari kegiatan yang dijalankan. Namun alangkah baiknya jika metode redudancy (pengulangan) juga bisa lebih sering digunakan dalam penyampaian pesan ke masyarakat agar pesan- pesan penting yang disampaikan secara berulang bisa lebih mudah diingat dan tentunya komunikator bisa dengan mudah mendapatkan perhatian dari khalayak.

\section{Pemilihan Penggunaan Media}

Memilih saluran atau media komunikasi harus mempertimbangkan karakteristik dan tujuan dari isi pesan yang ingin disampaikan, serta jenis media yang dimiliki oleh khalayak. Pemilihan media harus disesuaikan dengan tujuan yang ingin dicapai, karena setiap media komunikasi tentunya memiliki kelebihan dan kekurangan. Terlebih lagi jika implementasi suatu program/kegiatan berada di lingkup perdesaan, maka pemilihan media harus kita sesuaikan dengan kondisi dan situasi masyarakat/khalayaknya. Sama halnya yang dilakukan oleh pihak pengelola kegiatan SPP di Kelurahan Tomoni Kecamatan Tomoni pemilihan media yang digunakan sudah sesuai dengan kondisi khalayak yang ada. Dimana media yang paling dominan digunakan ialah melalui forum sosalisasi dengan menggunakan komunikasi langsung ke masyarakat.

\section{Peranan Komunikator}

Dalam penelitian ini, teori AIDDA digunakan untuk melihat peran komunikator sebagai penyampai pesan yang berperan penting. Strategi komunikasi yang dilakukan harus luwes sehingga komunikator sebagai pelaksana dapat segera mengadakan perubahan apabila ada suatu faktor yang mempengaruhi. Oleh karena itu, ada fakor penting pada diri komunikator bila ia ingin melancarkan komunikasi, yaitu daya tarik (source attractiveness) dan kreadibilitas sumber (source credibility) yang tentunya diiringi dengan rasa empati ke khalayak sasaran. Agar pesan benar-benar dapat diterima oleh khalayak sasaran, maka unit pengelola kegiatan dan pihak-pihak yang terkait dalam kegiatan SPP harus memiliki kreadibilitas dan daya tarik.

Dalam membangun kreadibilitas dan daya tarik di mata khalayak sasaran, pengelola kegiatan SPP langsung terjun sendiri bertindak sebagai komunikator, dalam hal ini pemerintah setempat yang ada di tingkat Kecamatan Tomoni maupun di tingkat Kelurahan Tomoni. Para pelaku yang telibat dalam pengelolaan kegiatan SPP sebelum mengimplementasikan ke masyarakat luas dan penerima manfaat mereka telebih dahulu mendapatkan pelatihan 
(training) sebagai pembekalan untuk melakukan penyebaran informasi dan tata cara pelaksanaan. Selain itu untuk membangun kreadibilitas dan daya tarik, pengelola kegiatan SPP juga menggandeng pihak pemerintah dari kabupaten sebagai tempat untuk melakukan konsultasi terkait tata cara pelaksanaan dan penyebaran informasi dalam kegiatan SPP. Kemudian pada saat mengadakan sosialisasi atau rapat/pertemuan pihak pengelola kegiatan juga melibatkan tokoh-tokoh masyarakat dan agama.

Sementara untuk melihat dan mengetahui bagaimana peranan komunikator yang dilakukan selama proses pengimplementasian program atau kegiatan SPP, maka yang tepat untuk ditanyakan mengenai hal ini ialah mereka yang melihat, menilai dan merasakan yaitu masyarakat penerima manfaat kegiatan SPP. Berdasarkan hasil penelitian, peranan komunikator dalam mengimplementasikan kegiatan SPP di Kelurahan Tomoni Kecamatan Tomoni di mata masyarakat penerima manfaat dinilai cukup bagus, dengan diberikannya arahan-arahan dan motivasi sebagai dorongan untuk peningkatan kualitas hidup mereka.

Masyarakat pada dasarnya akan tertarik menerima informasi suatu program/kegiatan yang datang dari luar dan akan mau berperan serta memberikan kontribusinya jika mereka merasakan ada manfaat yang dapat diambil.

\section{FAKTOR PENDUKUNG DAN \\ PENGHAMBAT DALAM \\ MENGIMPLEMENTASIKAN \\ KEGIATAN SIMPAN PINJAM \\ PEREMPUAN (SPP) PADA PNPM \\ MANDIRI PERDESAAN}

\section{Faktor Pendukung}

Berdasarkan hasil observasi dan wawancara kepada informan yang memenuhi kriteria maka ditemukanlah faktor-faktor yang mendukung dalam mengimplementasikan kegiatan SPP di Kelurahan Tomoni Kecamatan Tomoni, diantaranya; dukungan dari pemerintah. Karena program PNPM-MPd ini yang didalamnya termasuk kegiatan SPP merupakan amanat dari UU dan kebijakan dari negara maka faktor pendukung yang paling pertama ialah adanya dukungan dari pemerintah baik itu dari pusat, kabupaten, kecamatan, maupun desa/kelurahan.

Selain itu, dukungan dari segi financial. Dalam pelaksanaan sebuah program/kegiatan tentunya tidak lepas dari persoalan biaya. Adanya dukungan dari segi financial ini membuat implementasi kegiatan SPP ini seperti pengadaan sosialisasi atau pelatihan dan lain sebagainya mudah dilaksanakan. Dan dukungan yang tidak kalah pentingnya ialah dukungan dari masyarakat. Adanya dukungan serta antusiasme dari masyarakat terutama pada masyarakat penerima manfaat kegiatan SPP tentu akan melancarkan suksesnya sebuah program/kegiatan yang dijalankan.

Adanya dukungan dari berbagai pihak tentunya dapat melancarkan proses pelaksanaan suatu program atau kegiatan. Namun untuk lebih mengembangkan program tersebut pihak pengelola juga harus lebih giat untuk mencari dukungan lain yang tentunya bisa lebih menambah lancarnya proses pelaksanaan program. Seperti halnya pada kegiatan SPP ini, alangkah baiknya jika pihak pengelola kegiatan bisa mencari tambahan dukungan dengan mencoba bekerja sama ke berbagai pihak misalnya pengusaha yang memiliki badan usaha atau dinas pemerintah setempat yang dianggap bisa lebih mendukung proses pelaksanaan program. 


\section{Faktor Penghambat}

Jika ada faktor pendukung tentunya juga tidak lepas dari faktor penghambat. Berdasarkan hasil penelitian, ada beberapa faktor penghambat dalam mengimplementasikan kegiatan SPP di Kelurahan Tomoni Kecamatan Tomoni, diantaranya: pertama, terlambatnya pencairan dana. Hal ini di sebebkan laporan akir dari para pelaku yang terlibat dalam kegiatan SPP baik itu ditingkat Kecamatan maupun ditingkat Desa atau Kelurahan mengalami keterlambatan dalam peyetoran ke tingkat Kabupaten sehingga proses pencairan dana dari kegiatan SPP ini juga ikut terlambat.

Kedua, pelaku-pelaku yang terkait dalam kegiatan SPP baik itu ditingkat Kecamatan maupun Desa/Kelurahan ada yang aktif dan tidak aktif. Hal tersebut terjadi karena tidak adanya jasa atau upah tambahan yang diterima sebagai imbalan dalam membatu proses implementasi kegiatan SPP ini sehingga para pelaku tersebut juga merasa acuh tak acuh terhadap kegiatan ini. Tidak adanya upah tambahan yang diterima oleh para pelaku dalam kegiatan SPP ini khususnya ditingkat Kelurahan karena memang tidak disediakan atau tidak tertulis dalam PTO dan anggaran dana operasional dalam kegiatan SPP ini.

Ketiga, Susahnya mengatur waktu atau jadwal untuk mengadakan kegiatan. Hal tersebut dikarenakan situasi dan kondisi masyarakat yang terkadang tidak mendukung yang disebabkan oleh pekerjaan mereka. Keempat, masyarakat penerima manfaat terkadang lambat menyetor pembayaran. Selain itu, terkait dengan permasalah penunggakan pada kelompok SPP karena masih kurangnya pemahaman masyarakat terhadap pelaksanaan program PNPM-MPd. Kemudian adanya penyalahgunaan dana yang biasanya terjadi pada kelompok SPP baik itu dari ketua maupun anggota kelompok.

Pada dasarnya setiap program atau kegiatan tentu memiliki faktor pendukung dan penghambat dalam pelaksanaannya, baik yang berasal dari dalam organisasi (internal) maupun yang berasal dari luar organisasi (eksternal). Namun untuk menambah dukungan serta mengurangi hambatan yang ada tentunya dibutuhkan partisipasi dan kerjasama oleh semua pihak agar proses pengimplementasian suatu program/kegiatan dapat terkoodinasi dengan baik. Hal ini pula yang tentunya harus diperhatikan dan dilakukan oleh para pelaku yang terlibat dalam kegiatan SPP di Kelurahan Tomoni Kecamatan Tomoni dengan masyarakat penerima manfaat. Adanya partisipasi dan kerjasama yang terjalin dengan baik tentunya akan membuat faktor pengahambat yang dihadapi dalam proses pengimplementasiaan kegiatan SPP ini dapat berkurang.

\section{KESIMPULAN DAN SARAN}

\section{KESIMPULAN}

Berdasarkan hasil penelitian dan pembahasan, penulis akhirnya menarik kesimpulan dari penelitian mengenai Strategi Komunikasi Dalam Mengimplementasikan Kegiatan SPP Pada PNPM Mandiri Perdesaan di Kelurahan Tomoni Kecamatan Tomoni Kabupaten Luwu Timur, sebagai berikut:

1. Strategi komunikasi yang diterapkan pihak pengelola kegiatan di Kelurahan Tomoni Kecamatan Tomoni dalam pengimplementasian kegiatan SPP berkaitan dengan persoalan pengenalan khalayak; penyusunan pesan; penetapan metode penyampaian pesan; pemilihan penggunaan media; dan peranan komunikator. Terkait dengan pengenalan khalayak, yang menjadi sasaran dari kegiatan SPP ini ialah masyarakat yang masuk dalam kategori kelas menengah ke bawah. Mengenai penyusunan pesan dilakukan berdasarkan petunjuk teknis operasional (PTO) PNPM Mandiri perdesaan yang dilaksanakan melalui sosialisasi sebagai penyebaran informasi, rapat atau pertemuan, musyawarah dan pelatihan. Menyangkut dengan metode penyampaian pesan, pengelola kegiatan SPP di kelurahan Tomoni Kecamatan Tomoni mererapkan metode informatif, edukatif, dan persuasif. Sedangkan untuk pemilihan media yang digunakan dalam mengimplementasikan kegiatan SPP ini melalui media komunikasi secara langsung atau antarpribadi (personal), media tayang/visual (slide power point, video, gambar) dan media lini bawah seperti booklet, poster, selebaran, dan papan informasi. Sementara terkait dengan peranan komunikator dapat dilihat dengan adanya pemberian arahan dan motivasi kepada masyarakat penerima manfaat. 
2. Ada beberapa faktor yang menjadi pendukung dan penghambat dalam mengimplementasikan kegiatan SPP di Kelurahan Tomoni Kecamatan Tomoni Kabupaten Luwu Timur. Faktor pendukung tidak lain berasal dari pemerintah (pusat, kabupaten, kecamatan, desa atau kelurahan), finansial dan antusias masyarakat itu sendiri. Sementara untuk faktor penghambatnya ada juga dari pihak pemeritah dalam hal ini pihak pengelola serta pelaku-pelaku yang terlibat dalam kegiatan SPP dan juga dari masyarakat seperti; keterlambatan pembuatan laporan dan ketidakaktifan dari pelaku-pelaku yang terkait dalam kegiatan SPP, serta susahnya penjadwalan kegiatan untuk masyarakat.

\section{SARAN}

1. Penulis menyarankan agar pihak pengelola dan pelaku-pelaku yang terlibat (pemerintah setempat) lebih rutin lagi mengadakan kegiatan atau sosialisasi (minimal sebulan sekali) tekait dengan kegiatan SPP sehingga masyarakat bisa mengetahui lebih banyak informasi dan tentunya tidak akan ketinggalan informasi dan juga masyarakat bisa lebih berpartisipasi lagi dalam pelaksanaannya. Disamping itu, pihak pemerintah pun dapat dengan mudah melakukan controling pada kelompok SPP.

2. Kemudian disarankan agar strategi komunikasi dapat terus diperbaharui agar masyarakat tidak jenuh, dan masalah pendanaan bukan dijadikan alasan utama dalam proses penyampaian pesan atau informasi kepada masyarakat.

3. Bagi pemerintahan desa/kelurahan, agar dapat meningkatkan kerjasama atau menjalin komunikasi yang baik dengan pengelola kegiatan SPP PNPM Mandiri di tingkat kecamatan agar tidak menemukan hambatan dalam menjalankan pelaksanaannya.

\section{REFERENSI}

Cangara, H. 2010. Pengantar Ilmu Komunikasi. Jakarta: Rajawali Pers.

Cangara, H. 2013. Perencanaan dan Strategi Komunikasi. Jakarta: Rajawali Pers.

Direktorat Jendral Pemberdayaan Masyarakat dan Desa. 2014. Petunjuk Teknis Operasional PNPM Mandiri. Jakarta: Kementerian Dalam Negeri Republik Indnesia.

Effendy, Onong. U. 2004. Dinamika Komunikasi. Bandung: PT Remaja Rosdakarya

Effendy, Onong. U. 2009. Ilmu Komunikasi Teori dan Praktek. Bandung: PT Remaja Rosdakarya.

Kriyantono, Rachmat. 2006. Teknik Praktis Riset Komunikasi. Jakarta: Kencana.

Nihayah, A. Z. 2015. 'Pengaruh Program Simpan Pinjam Kelompok Perempuan Terhadap Pendapatan Usaha Mikro Kecil Dan Poverty Rediction Dalam Perspektif Ekonomi Islam (Studi Kasus PNPM Mandiri Perdesaan Kecamatan Bangilan, Tuban)'. Jurnal Ekonomi dan Hukum Islam, Vol.5, No. 2 ISSN: 2088-6365 eISSN : 2477-5576, 4.

PNPM. 2012-2013. Bangkit Bersama Untuk Mandiri. Jakarta Pusat: Sekretariat Pokja Pengendali PNPM Mandiri.

Poentarie, E. 2013. 'Penerapan Strategi Komunikasi Pada Plick Nanggulan 2'. Jurnal Studi Komunikasi dan Media, Vol. 17 No. 2 (Juli - Desember 2013) Hal : 163 - 172, 163-172.

Tim Pelaksana Pengendali PNPM Mandiri. 2008. Pedoman Pelaksanaan Strategi Komunikasi Program Nasional Pemberdayaan Masyarakat (PNPM) Mandiri. Jakarta: Deputi Menko Kesra Bidang Koordinasi Penanggulangan Kemiskinan.

Usman, H., \& Akbar, P. S. 2009. Metode Penelitian Sosial. Jakarta: Bumi Aksara. 


\section{DAFTAR TABEL}

Tabel 1. Daftar Informan

\begin{tabular}{|c|c|c|c|c|c|}
\hline No & Nama & $\begin{array}{c}\text { Usia } \\
\text { tahun })\end{array}$ & $\begin{array}{c}\text { Tingkat pendidi- } \\
\text { kan }\end{array}$ & Peker-jaan & Kete-rangan \\
\hline 1 & $\begin{array}{c}\text { Abadi } \\
\text { Adam }\end{array}$ & 43 & Sarjana & Pega-wai & Ketua UPK \\
\hline 2 & Sumian-to & 50 & sarjana & PNS & $\begin{array}{c}\text { Fasilitator kecama- } \\
\text { tan }\end{array}$ \\
\hline 3 & $\begin{array}{c}\text { Perdi } \\
\text { paranda }\end{array}$ & 45 & sarjana & PNS & Ketua tim verifikasi \\
\hline 4 & Zulkar-nain & 47 & SMA & PNS & $\begin{array}{c}\text { Staf Kelura-han } \\
\text { Tomoni }\end{array}$ \\
\hline 5 & Roswati & 42 & SMA & Peda-gang & $\begin{array}{c}\text { Ketua kelompo-k } \\
\text { SPP }\end{array}$ \\
\hline 6 & Hasnita & 27 & SD & Peda-gang & $\begin{array}{c}\text { Ketua kelompo-k } \\
\text { SPP }\end{array}$ \\
\hline 7 & Ummi & 60 & SD & Peda-gang & $\begin{array}{c}\text { Ketua kelompo-k } \\
\text { SPP }\end{array}$ \\
\hline 8 & Siti Amina-h & 29 & SMA & Peda-gang & $\begin{array}{c}\text { Ketua kelompo-k } \\
\text { SPP }\end{array}$ \\
\hline
\end{tabular}

Sumber: Hasil Olahan Data Primer, 2017 